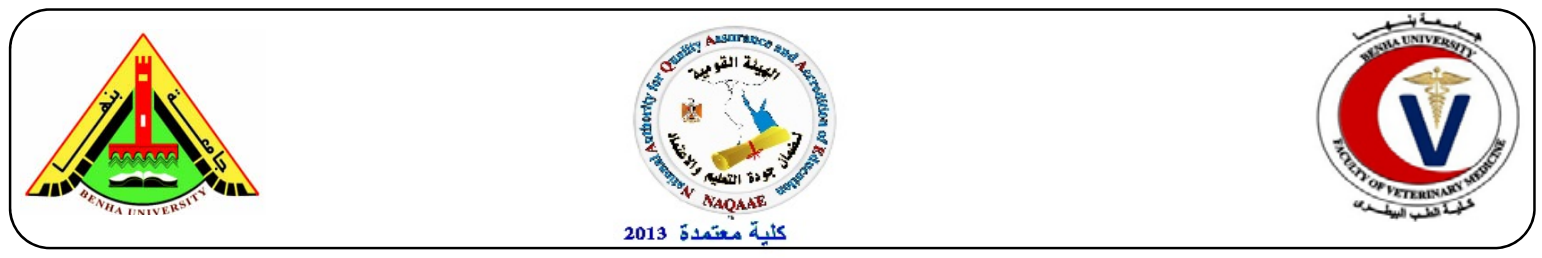

\title{
Conventional and modern identification techniques for identification of Salmonellae isolated from some meat products
}

\author{
Hemmat M. Ibrahim¹, Mohamed A. Hassan', Reham A. Amin ${ }^{1}$, Nesreen, Z. Eleiwa ${ }^{2}$, Samaa, S. \\ Nadim $^{2}$ \\ ${ }^{1}$ Department of Food Hygiene, Faculty of Veterinary Medicine, Benha University. ${ }^{2}$ Meat hygiene, \\ animal health research institute Tanta Branch. ${ }^{3}$ Department of general medical, Centeral labora- \\ tories, Al-Azhar University.
}

\begin{abstract}
A B S T R A C T
This study was conducted to determine the prevalence of Salmonella pathogens in minced meat, kofta, beef burger and sausage ( 25 samples of each), weight of each sample10gm were collected from different shops and supermarkets in Cairo governorate. The obtained results indicated that the incidence of Salmonellae isolated from examined samples were (2)8\%, (2) $8 \%, 0 \%$ and (1) $4 \%$ of minced meat, kofta, beef burger and sausage respectively. The serotypes of 5 positive Salmonella isolates in the examined meat product samples were Salmonella Typhimurium, Salmonella Muenster and Salmonella Enteritidis. Modern identification techniques as Enzyme-linked immunosorbent assay (ELISA), Latex Agglutination and Polymerase Chain Reaction (PCR). These techniques are considered powerful, rapid procedure with both sensitivity and specificity for quick detection and identification of specific pathogenic bacteria from different sources. The results obtained by applying PCR on 5 isolated Salmonella strains show presence of common Salmonella gene in isolated strains, the identification of isolated Salmonella strains show positive results by ELISA and latex agglutination technique only confirm Salmonella Typhimurium and Salmonella Enteritidis. Since presence of these food poisoning microorganisms as Salmonella constitute a potential risk to public health, these findings underscore the need to control them and to limit bacterial multiplication in meat products.
\end{abstract}

Keywords: Salmonellae, Meat Products, ELISA, PCR.

(http://www.bvmj.bu.edu.eg)

(BVMJ-29(2): 262-267, 2015)

\section{INTRODUCTION}

$\mathrm{F}$ ood-borne pathogens are a major threat to food safety, especially in developing countries where hygiene and sanitation facilities are often poor, Salmonella enterica, E.coli $\mathrm{O}_{157}: \mathrm{H}_{7}$ and Shigella spp. are among the major causes of outbreaks of food borne diseases (Ahmed and Shimamoto, 2013). Also food borne diseases remain a major problem and one of public health concern. Epidemiological data show an increasing incidence of infectious diarrhea (Osservasalute, 2008). Salmonellae might cause 1.3 million human food borne illnesses and more than 500 deaths each year in the United States,

representing an annual estimated cost to the economy of approximately $\$ 2.4$ billion, Salmonella enterica comprises more than 2,500 serotypes (Callaway et al., 2008). Conventional culture methods have traditionally been considered the "gold standards" for the isolation and identification of food borne pathogens. However, culture methods are laborintensive and time-consuming. PCR assay for the detection of E. coli and Salmonella in a variety of food and food-animal matrices was applied (China et al., 1996). Rapid and sensitive detection techniques for food borne pathogens are important to the 
food industry. However, traditional detection methods rely on bacterial culture in combination with biochemical tests, a process that typically takes 4 to 7 days to complete, developing a novel PCR assay for detection of all food borne pathogenic bacteria could be completed in less than $24 \mathrm{~h}$ (Jeong soon et al., 2007). The enzyme immunoassay (EIA) and the enzyme-linked immunosorbent assay (ELISA) are the most commonly used techniques for rapid detection of pathogen and toxins. While Polymerase Chain Reaction (PCR) has been established for quite some time, but recently has enjoyed renewed interest by food industry scientists. PCR involves detection of specific gene fragments by in-vitro enzymatic amplification of the target DNA, followed by detection of the amplified DNA molecule by electrophoresis, ELISA or other techniques (Purnendu and Vasavada, 2001).

Therefore, the present study was planned out to throw out light on: Conventional recovery methods, to detect prevalence of Salmonella in examined meat products. Bacteriological and serological identification of the isolates. Applying modern techniques as ELISA, Latex agglutination technique and Polymerase chain reaction (PCR) were performed to confirm identification of isolated Salmonella strains.

\section{MATERIAL AND METHODS}

\subsection{Collection of samples}

One hundred random samples of meat products represented by minced meat, kofta, beef burger and sausage (25of each), sample weight $10 \mathrm{gm}$ were collected from different supermarkets and from retail stores in Cairo governorate. The collected samples were aseptically collected in sterile polyethylene bags. All samples were examined bacteriological for detection of Salmonellae.

2.2. Isolation and identification
Salmonellae

The technique recommended by (ISO, 1993) by using Xylose Lysine Desoxycholate (X.L.D) agar media. The suspected colonies are (non - lactose fermenters, red colonies with or without black center, suspected colonies for Salmonellae were morphologically and biochemically identified.

\subsection{Serotyping of Salmonellae}

Serological identification of Salmonellae was carried out according to Kauffman White scheme (Kauffman, 1974) for the determination of Somatic $(\mathrm{O})$ and flagellar (H) antigens using Salmonella antiserum (DENKA SEIKEN Co., Japan).

\subsection{ELISA as a modern method for detection of Salmonellae}

ELISA Procedure for detection of Salmonella species, Bio-Rad protein elution unit was used in ELISA as coating antigens according to (Zamora et al., 1999).

\subsection{Latex Agglutination as a modern method for detection of Salmonellae}

The commercial latex agglutination kits namely Dry spot (Oxoid, Basingstoke, Hampshire, England) were used for rapid serological identification of the isolated Salmonellae according to (katz, 2013).

\subsection{Polymerase chain reaction (PCR) as a modern method for detection of specific gene by usingPrimer sequences of Salmonellae}

\section{RESULTS}

It is evident from the results recorded in table (2) that the incidence of Salmonellae in minced meat, kofta, beef burger and sausage were $2(8 \%), 2(8 \%), 0(0 \%)$ and 1 (4\%) respectively. Also show the serological identification of 5 positive Salmonella isolates in the examined meat product samples were Salmonella Typhimurium, Salmonella Muenster and Salmonella Enteritidis from examined meat product samples, according to ESS (2005) of Salmonellae, acceptable samples were 
Table (1): OMPC primer as specific primer for demonstration of Salmonella species by PCR was used in the following

\begin{tabular}{llll}
\hline Target gene & Oligonucleotide sequence $\left(5^{\prime} \rightarrow 3^{\prime}\right)$ & Product size (bp) & Reference \\
\hline OMPC(F) & 5'ATCGCTGACTTATGCAATCG '3 & 204 & Garaizar et al. \\
OMPC(R) & 5'CGGGTTGCGTTATAGGTCTG '3 & & (2002) \\
\hline
\end{tabular}

Table (2): Incidence of Salmonellae in examined meat products samples by conventional method and serological identification

\begin{tabular}{|c|c|c|c|c|c|c|}
\hline \multirow[b]{2}{*}{ products } & \multirow{2}{*}{$\begin{array}{c}\text { Number } \\
\text { of } \\
\text { isolates }\end{array}$} & \multirow[b]{2}{*}{$\%$} & \multirow[b]{2}{*}{ Serotypes } & \multirow[b]{2}{*}{ Group } & \multicolumn{2}{|c|}{ Antigenic structure } \\
\hline & & & & & $\mathrm{O}$ & $\mathrm{H}$ \\
\hline $\begin{array}{l}\text { Minced meat } \\
(n=25)\end{array}$ & 2 & 8 & $\begin{array}{l}\text { S.Enteritidis } \\
\text { S.Muenster }\end{array}$ & $\begin{array}{l}D_{1} \\
E_{1}\end{array}$ & $\begin{array}{c}1,9,12 \\
3,10,15,34\end{array}$ & $\begin{array}{c}\mathrm{g}, \mathrm{m} \\
\mathrm{e}, \mathrm{h}: 1,5\end{array}$ \\
\hline Kofta $(n=25)$ & 2 & 8 & $\begin{array}{l}\text { S.Typhimurium } \\
\text { S.Enteritidis }\end{array}$ & $\begin{array}{l}\mathrm{B} \\
\mathrm{D}_{1}\end{array}$ & $\begin{array}{l}6,7,14 \\
1,9,12\end{array}$ & $\begin{array}{c}\mathrm{r}: 1,2 \\
\mathrm{~g}, \mathrm{~m}\end{array}$ \\
\hline $\begin{array}{l}\text { Beef burger } \\
(\mathrm{n}=25)\end{array}$ & 0 & 0 & - & - & - & - \\
\hline Sausage $(n=25)$ & 1 & 4 & S.Typhimurium & B & $6,7,14$ & $\mathrm{r}: 1,2$ \\
\hline total & 5 & 5 & & & & \\
\hline
\end{tabular}

$92 \%, 92 \%, 100 \%, 96 \%$ in minced meat, kofta, beef burger and sausage, respectively.

Table (3): Acceptability of the examined samples of meat products based on their contamination with Salmonellae according to ESS (2005)

\begin{tabular}{lcc}
\hline products & $\begin{array}{c}\text { Number } \\
\text { of } \\
\text { isolates }\end{array}$ & $\%$ \\
\hline $\begin{array}{l}\text { Minced meat } \\
(\mathrm{n}=25)\end{array}$ & 23 & 92 \\
Kofta $(\mathrm{n}=25)$ & 23 & 92 \\
Beef burger $(\mathrm{n}=25)$ & 25 & 100 \\
Sausage $(\mathrm{n}=25)$ & 24 & 96 \\
\hline
\end{tabular}

Results achieved in Table (4) show the confirmation of identified Salmonellae serotypes by using ELISA and Latex agglutination technique, PCR Photo revealed that presence of common gene in Salmonella species that confirm that all isolates is Salmonellae.

Table (4): Confirmation of identified Salmonellae serotypes by using different modern identification techniques

\begin{tabular}{lcc}
\hline Serotypes & $\begin{array}{c}\text { Indirect } \\
\text { ELISA }\end{array}$ & $\begin{array}{c}\text { Latex } \\
\text { Agglutination }\end{array}$ \\
\hline S.Typhimurium & $+\mathrm{ve}$ & $+\mathrm{ve}$ \\
S.Enteritidis & $+\mathrm{ve}$ & $+\mathrm{ve}$ \\
S.Muenster & $+\mathrm{ve}$ & $-\mathrm{ve}$ \\
\hline
\end{tabular}




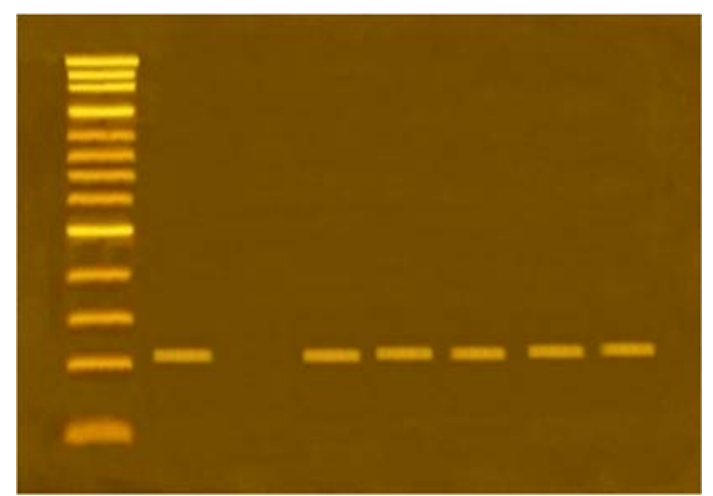

Fig (1): Agarose gel electrophoresis of PCR amplification products using specific primer (OMPC) of Salmonella species. Lane M: 100 bp ladder as molecular size DNA marker. Lane 1: Control positive for Salmonella species. Lane 2: Control negative for Salmonella species. Lanes 3, 4, 5, 6 and 7: Positive Salmonella strains

\section{DISCUSSION}

Salmonellosis is still the most important food borne infection in man, where contamination occurs within slaughterhouses and during further processing of meat destined for human consumption, the food may look and smell fine, but it's not. All foods, including vegetables, may become contaminated, although most cases of food poisoning involve foods from animal sources such as meat, poultry and others (OSF Health Center, 2006).

The results of obtained in (Table2) indicate incidence of Salmonella in minced 8\% nearly similar results reported by (Khalafalla, 1988) incidence of Salmonella $8 \%$. Less results obtained by (Bosilevac et al., 2009) and (Cetin et al., 2010) with percentage $4.2 \%$ and 3.14 , respectively. On the other hand higher results reported by (El. Mossalami et al., 1989) $12 \%$ and (Eleiwa, 2003) 16\%. Salmonellae could be detected in kofta with percentage $8 \%$ lower results obtained by (El. Mossalami, 2003) and (Torky, 2004) with percentage 5\% and failed to be isolated by (El-sherief, 2009) and (Al-Mutari, 2011). In beef burger Salmonellae failed to be detected similar results were obtained by (Hefnawy, 1980) and (El-Mossalami, 2003). Concerning sausage Salmonellae isolated by percentage $4 \%$ nearly similar results obtained by (Elsherief, 2009) and (Al-Mutari, 2011) with percentage $6.6 \%$ and $8 \%$, respectively.

Also in (Table2) Salmonellae isolated from minced meat identified serologically as Salmonella Enteritidis from one sample and Salmonella Muenster from other sample. In Kofta one sample belong to Salmonella Typhimurium while other sample serotype was Salmonella Enteritidis. While in sausage Salmonella was identified serologically as Salmonella Typhimurium. Presence of pathogens like Salmonella indicates substandard hygiene during processing, storage and retailing which represent a high risk to consumer. Data showed in (Table 3) indicated that Salmonellae could not be detected in beef burger so $100 \%$ of samples are accepted and agreed with (ESS, 2005). On the other hand percentage of samples accepted and agreed with (ESS, 2005) were $92 \%$ in minced meat, $92 \%$ kofta and $96 \%$ sausage. According to ESS No 1973 (2005) he meat products must not contain microorganism which are considered as hazard for public health as Salmonella.

Table (4) show using of modern techniques as ELISA and latex agglutination technique in confirmation of Salmonella serotypes Salmonella Typhimurium, Salmonella Enteritidis and Salmonella Muenster. The two serotypes Salmonella Typhimurium and Salmonella Enteritidis both give positive result by using ELISA and latex agglutination technique, while Salmonella Muenster identified only by give positive result by using ELISA but cannot identified by using latex agglutination technique and give negative results as there is no antisera available for Salmonella Muenster strain.

While photo (1) showed agarose gel electrophoresis of PCR amplification products using specific primer (OMPC) of Salmonella species to confirm 5 isolated Salmonella strains by detect common Salmonella gene. Results recorded reveled positive results for examined 5 Salmonella 
strains showed in Lane 3, 4, 5, 6 and 7 as they agreed with Lane I at 204-bp band which represent positive control for Salmonella strains.

Although conventional pathogen detection methods are sensitive, they lag behind the analytical methods by detection time. Therefore, new rapid methods are considered necessary for better performance. Though, numerous research efforts have been made during the past decades and in recent years for food borne pathogen detection. Since food-borne pathogens are mostly present in very low numbers in the middle of millions of other bacteria, it is very difficult to detect them. So there are more chances for these microorganisms that may get lost during detection. Therefore, modern detection techniques which are reliable, rapid, accurate, simple, sensitive, selective and cost effective has to be developed (Arshak et al., 2010).

\section{REFERENCES}

Ahmed, A.M., Shimamoto, T. 2014. Isolation and molecular characterization of Salmonella enterica, Escherichia coli O157:H7 and Shigella spp. from meat and dairy products in Egypt. Int. J. Food Microbiol., 3:168-169:57-62.

Al-Mutairi, M.F. 2011. The Incidence of Enterobacteriaceae causing food Poisoning in Some Meat Products. Adv. J. Food Sci. Technol., 3(2): 116121.

Arshak, K., Vijayalakshmi, V., Olga, K., Kamila, O. 2010. An overview of foodborne pathogen detection: In the perspective of biosensors. Biotechnology Advances 28: 232 254

Bosilevac, J., Guerini, M., Kalchayanand, N., Koohmaraie, M. 2009. Prevalence and characterization of salmonellae in commercial ground beef in the United States.
Callaway, T.R., Edrington, T.S., Anderson, R.C., Byrd, J.A., Nisbet, D.J. 2008. Gastrointestinal microbial ecology and the safety of our food supply as related to Salmonella. J. Anim Sci., 86: E163.

Cetin, O., Baris, E., Colak, H., Ergun, O., Demir, C. 2010. The microbiological, serological and chemical qualities of minced meat marketed in İstanbul. Turk. J. Vet. Anim. Sci., 34(4): 407412.

China, B., Pirson, V., Mainil, J. 1996. Typing of bovine attaching and effacing E. coli by multiplex in vitro amplification of virulence associated genes. Appl. Environ. Microbiol. 62: 3462.

Egyptian Standards specification (ESS). 2005. For beef burger No. 1688.

Egyptian Standards specification (ESS). 2005. Minced meat No. 1694.

Egyptian Standards specification (ESS). 2005. Sausage No. 1972.

Egyptian Standards specification (ESS). 2005. Beef Kofta No. 1973.

Eleiwa Nesreen, H.E. 2003. Effect of chemical preservatives on food manufactured meat products. Ph.D., Thesis, (Meat Hygiene), Fac. Vet. Med. Moshtohor, Zagazig Univ.

El-Mossalami, E.I.K. 2003. Risk assessment of ready prepared meat products. Ph. D. Thesis, (Meat Hygiene), Fac. Vet. Med., Cairo. Univ.

EL-Mossalami, E., Safwat, A., Abdel Rahim, L., El- Sawah, H. 1989. Salmonellae in locally produced meat products. J. Egypt. Vet. Med. Assoc., 49: 99.

El-Sherif, A.M. 2009. Different serotypes of E. coli and Salmonellae in some Meat Products and their behavior during different heat treatments and cold storage. Ph. D. Thesis Fac. Vet. Med. Cairo. Univ.

Garaizar, J., Porwollik, S., Echeita, A., Rementeria, A., Herrera, S., Wong, R.M., Frye, J., Usera, M.A., Mc - 
Clelland, M. 2002. DNA microarray based typing of an atypical monophasic salmonella enterica serotype. J. Clin. Microbiol., 40: 2074- 2078.

Hefnawy, Y. 1980. Studies on the sanitary improvement of processed hamburger in Egypt. Ph. D. Thesis Fac. Vet. Med. Assuit Univ.

International organization for standardization" ISO". 1993. ISO 6579: 1993 (E). General guidance on methods for the detection of Salmonella.

Jeong Soon, K., Lee, G.G., Park, J.S., Jung, Y.H., Kwak, H.S., Kim, S. B., Nam, Y.S., Kwon, S.T. 2007. A novel multiplex PCR assay for rapid and simultaneous detection of five pathogenic bacteria: Escherichia coli O157:H7, Salmonella, Staphylococcus aureus, Listeria monocytogenes, and Vibrioparahaemolyticus. J. Food Prot., 70(7):1656-62.

Katz, D.S. 2013. Bacterial agglutination protocol. American Society for Microbiology. Microbelibrary, April2013. http://www.Microbelibrary.org/library/8-authors/239-dsue-katz.
Kauffman, G. 1974. Kauffmann white scheme. J. Acta. Path. Microbiol. Sci., 61:385.

Khalafalla, F.A. 1988. Sanitary status of meat products and fish in Beni Seuf governorate. Ph. D. Thesis (Meat Hygiene), Fac. Vet. Med. Cairo University.

OSF Health Center. 2006. Diarrhea and Diarrheal illnesses. Revolution health. Com /Conditions/digestive / diarrhea/ causes / traveler's diarrhea.

Osservasalute. 2008. Health status and quality of the Italian regions. Report 2008: 175 -7.

Purnendu, C., Vasavada, P. 2001. Getting Really Rapid Test Results: Advances in Pathogen and Toxin Detection for the Food Industry. www.food safety magaziene.Com/magazine-archive1/.

Torky, A.A.S. 2004. Trials for inhibition of some food poisoning microorganisms in meat products. Ph. D. Thesis, Fac. Vet. Med., Cairo Univ.

Zamora, B., Hartung, M., Hildebrant, G. 1999. Simplified preparation of specific bacterial antigens for ELISA and other serological techniques. J. Vet. Med., 46: 1-7. 